ISSN: 2146-3042

DOI: 10.25095/mufad.756186

\title{
Bağımsız Denetimde Zorunlu Rotasyonun Denetçi Bağımsızlığı ve Denetim Kalitesine Etkisi ve Rotasyon ile Denetim Kalitesi Arasındaki İlişkide Denetçi Bağımsızlığının Aracılık Rolü: Bağımsız Denetçilerin Algılarına Yönelik Bir Araştırma*
}

\author{
Seden ÖZGER** \\ Osman TUĞAY***
}

\section{$\ddot{O Z Z T T}$}

Günümüzde denetimde rotasyon uygulamasının, denetçi bağımsızlığı ve denetim kalitesini etkilediği yönündeki çeşitli çalışmalar denetimde rotasyon uygulamasını tartışmalı bir hale getirmiştir. Bu çalışmanın amacı, bağımsız denetçilerin algılarına göre denetimde zorunlu rotasyonun denetçi bağımsızlı̆̆ ve denetim kalitesine etkisi ve rotasyon ile denetim kalitesi arasındaki ilişkide denetçi bağımsızlı̆̆ının aracı rolünü tespit etmektir. Bu doğrultuda Kamu Gözetim Kurumu tarafindan yetkilendirilen bağımsız denetim firmalarında çalışan denetçilere anket formu uygulanmıştır. Elde edilen veriler SPSS 22.0 paket programı ile analiz edilerek ortaya çıkan sonuçlar istatistiksel olarak değerlendirilmiştir. Denetçilerin algılarından elde edilen sonuçlara göre; denetimde rotasyonun denetçi bağımsızlı̆̆ ve denetim kalitesini olumlu yönde etkilediği ve rotasyon ile denetim kalitesi arasında denetçi bağımsızlı̆̆ının aracılık etkisi olduğu tespit edilmiştir.

Anahtar Kelimeler: Denetimde Rotasyon, Denetçi Bağımsızlı̆̆ı, Denetim Kalitesi.

JEL Sinıflandırması: M40, M41, M42.

The Effect of Mandatory Rotation on Auditor Independence And Audit Quality in Independent Audit and Intermediary Role Of Auditor Independence in Relationship Between Rotation and Audit Quality: A Study on The Perception of Independent Auditors

\section{ABSTRACT}

Today, studies about the effect of audit rotation on auditor independence and audit quality have made use of audit rotation highly controversial topic. The purpose of this study is to explore the effect of mandatory rotation on auditor independence and audit quality in audit and to determine the intermediary role of auditor independence on the relation between rotation and audit quality according to the perceptions of independent auditors. Within this scope, a survey is applied on independent auditors in independent audit companies authorized by Public Oversight Board. The data that is gathered through surveys is analyzed with SPSS 22.0 and results are interpreted with statistical perspective. According to the results; use of audit rotation have positive effect on auditor independence and audit quality and there is intermediary effect of auditor independence in the relationship between rotation and audit quality.

Keywords: Audit Rotation, Auditor Independence, Audit Quality

Jel Classification: M40, M41, M42.

\footnotetext{
* Bu makale, "Bağımsız Denetimde Zorunlu Rotasyonun Denetçi Bağımsızlığı ve Denetim Kalitesine Etkisi: Bağımsız Denetçilerin Algısına Yönelik Bir Araştırma', başlıklı Yüksek Lisans Tezinden üretilmiştir.

Makale Gönderim Tarihi: 27.07.2019, Makale Kabul Tarihi: 14.11.2019, Makale Türü: Nicel Araştırma

** Mehmet Akif Ersoy Ünivesitesi, Sosyal Bilimler Enstitüsü, ORCID ID: 0000-0003-1979-1925

*** Doç. Dr., Mehmet Akif Ersoy Üniversitesi, İktisadi ve İdari Bilimler Fakültesi, otugay@mehmetakif.edu.tr, ORCID ID: 0000-0001-8733-7471.
} 


\section{GİRIŞ}

Bağımsız denetim, işletmelerin hazırlamış oldukları finansal tabloların doğruluğu ve güvenilirliği konusunda ilgili taraflara makul bir güvence sağlamak amacıyla tarafsız bir şekilde yeterli ve uygun kantların toplanarak elde edilen bu kanıtların değerlenip raporlanması sürecidir (Selimoğlu vd., 2015: 12-16). Ekonomik faaliyetlerin gelişmesi, çokuluslu şirketlerin artması, muhasebe işlemlerinin ve finansal tabloların karmaşık bir hale gelmesi doğru ve güvenilir bilgilere ulaşmayı zorlaştırmaktadır (Güredin, 2008: 9). Bu durum ilgili tarafların doğru ve güvenilir bilgi ihtiyacını karşılamak amacıyla bağımsız denetimin önemini arttırmıştır. Ancak 2000'li yıllarda yaşanan Enron, WorldCom ve Xerox gibi şirketlerin denetiminde hataların tespit edilememesi ve bunların ortaya çıkarılmaması nedeniyle denetçinin bağımsızlığ 1 konusunda şüpheler yaratmış ve yatırımcıların finansal tablolara olan güvenleri önemli ölçüde zedelenmiştir (Dinç ve Cengiz, 2014: 222). Bu durum mevcut yasal düzenlemelerin revize edilmesini gündeme getirmiş ve 2002 y1lında SrbanesOxley yasası ile denetimde rotasyon zorunlu hale getirilmiştir (Haftacı, 2016: 39).

Denetimde rotasyon uygulaması ile denetçi-müşteri arasındaki uzun süreli iş ilişkisinden dolayı oluşabilecek yakınlık tehdidinin önlenerek denetçinin hizmetlerinde daha bağımsız hareket etmesi ve böylece denetim kalitesinin arttırılması amaçlanmıştır. Ancak denetimde rotasyon uygulamasının fayda ve maliyetleri konusunda çeşitli iddiaların varlığı denetimde zorunlu rotasyonu tartışmalı bir hale getirmiştir.

Bu çerçevede çalışmanın amacı; bağımsız denetimde zorunlu rotasyon uygulamasının denetçi bağımsızlı̆̆ 1 ve denetim kalitesine etkisi ile ilgili bağımsız denetçilerin algılarını belirlemek ve rotasyon ile denetim kalitesi arasındaki ilişkide denetçi bağımsızlığının aracılık etkisini tespit etmektir. Bu kapsamda ilk olarak denetimde rotasyon, denetçi bağımsızlığı ve denetim kalitesi arasındaki ilişki ele alınmış ve konu ile ilgili literatürdeki çalışmalara yer verilmiştir. Daha sonra Kamu Gözetim Kurumu (KGK)'na kayıtlı denetim firmalarında çalışan denetçilerin algılarına yönelik yapılan araştırma bulgularına ve son olarak da elde edilen bulguların değerlendirilmesi yapılarak sonuç ve önerilere yer verilmiştir.

\section{DENETIMDE ZORUNLU ROTASYON, DENETÇİ BAĞIMSIZLIĞI VE DENETIM KALITESII İLIŞKISII}

Dünyada yaşanan finansal skandallar yatırımcıların denetçi bağımsızlı̆̆ı ve denetime olan güvenlerini zedelemiş, dolayısıyla sermaye piyasalarına olan güvenlerini de azaltmıştır. $\mathrm{Bu}$ nedenle denetçilerin bağımsızlığını arttırmak ve piyasalara olan güveni tekrar sağlamak amacıyla denetimde rotasyon zorunlu hale getirilmiştir. Denetimde rotasyon, denetçi/denetim firmasının bir müşterisine belirli bir süre vermiş olduğu denetim hizmetinden sonra aynı müşteriye tekrar denetim hizmeti verebilmesi için belirli bir süre ara vermesidir (Doğan, 2016: 2). Denetimde zorunlu rotasyon uygulaması ile denetçinin bağımsızlı̆̆ 1 arttırılarak denetim hizmetlerinin kaliteli bir denetimle sonuçlanarak bilgi kullanıcılarına ihtiyaç duydukları doğru bilgilerin sağlanması amaçlanmıştır.

Denetçinin aynı müşteriye vermiş olduğu denetim hizmet süresinin uzun olması, denetçi ile müşterisi arasında yakınlık oluşmasına neden olarak finansal tablolardaki önemli 
yanlışlıkların tespit edilme olasılı̆̆ını azaltabilmekte veya çıkar ilişkisinden dolayı müşteri lehine raporlamayı teşvik edebilmektedir. Bu da kaliteli denetimin gerekliliği olan önemli yanlışlıkların tespiti ve bu yanlışlıkların raporlanmasını olumsuz etkileyecektir.

Denetim hizmet süresinin uzunluğu denetçinin sürekli tekrarlanan rutin çalışmalar nedeniyle olayları doğru görememe ya da değerlendirememe riskini ortaya çıkarabilmektedir. Gözden kaçırılarak tespit edilemeyen önemli bir yanlışlık denetim kalitesinin düşmesine neden olacaktır. Denetimde rotasyon ile bu riskler ortadan kaldırlarak daha objektif bir değerlendirme yapılması sağlanacaktır (Şavlı, 2016: 41).

Denetim sözleşmesinin ilk yıllarında denetçi denetim sürecinde göstermiş olduğu dikkat ve özeni sonraki yıllarda göstermeyebilir. Denetimde rotasyon uygulaması ile denetime getirilecek olan yeni bir bakış açısı finansal tablolarda önceden tespit edilemeyen veya göz ardı edilen yanlışlıkların tespit edilmesini sağlayacaktır (Barton, 2002: 8).

Bağımsız denetim, bilgi kullanıcılarına finansal tablolara ilişkin doğru ve güvenilir bilgi sağlamada vazgeçilmez bir unsurdur. Bu unsur denetçinin bağımsızlı̆ının arttırılması ve denetim kalitesi ile doğrudan ilişkilidir (Tuan, 2015: 291-302).

KGK tarafından yayımlanan Bağımsız Denetim Yönetmeliği’nin 22. Maddesine göre bağımsızlık, denetim firmalarının ve denetçilerin denetim çalışmalarında denetlenen firmadan bağımsız ve tarafsız olmaları, hiçbir şekilde denetlenen firmaların karar alma süreçlerine katılmamaları ve bağımsızlıklarını ortadan kaldırabilecek özel durumların bulunmaması şeklinde tanımlanmıştır. Denetim kuruluşu ve denetçiler denetim çalışmalarını esasen ve şeklen bağımsız olarak gerçekleştirmektedirler. Esasta bağımsızlık; denetçinin dürüst, tarafsız ve mesleki şüphecilik içinde hareket etmesini teminen, mesleki yargısını olumsuz etkileyecek durumlardan etkilenmeden görüş̧ oluşturmasıdır. Şekilde bağımsızık ise; denetim firması, denetçi veya güvence ekibinin konuya ilişkin her türlü durum ve şartları değerlendiren makul ve bilgi sahibi üçüncü kişilerde, dürüstlük tarafsızlık ve mesleki şüphecilikten ödün verildiği izlenimini oluşturabilecek durum ve davranışlardan kaçınmasıdır (BDY, 2012: mad. 22).

Denetçi bağımsızlı̆̆ , denetim faaliyetini gerçekleştiren denetçinin hizmetlerinde tarafsız, dürüst ve objektif davranmasıdır. Başka bir ifadeyle denetçi bağımsızlığı, denetçinin müşteri baskısına direnerek bu baskı ve faktörlerin etkisi altında kalmadan objektif bir şekilde karar almasidır (Knapp, 1985: 202-203, ISB, 2000: para. 4).

Denetim kalitesi, denetim çalışmasının sonunda ulaşılan kanaatin güvenirliliğidir. İşletme ile ilgili karar vericilerin verecekleri kararların doğruluğu paylaşılan bilgilerin doğruluğu ve şeffaflığ ile doğrudan ilişkilidir (Selimoğlu, vd. 2017:84). Denetim kalitesi, denetim firmasının ve denetçinin bünyesindeki iç süreçlerinin belirli bir kalite seviyesinde, arzu edilen sonuçları sağlayarak bunu güvence altına alacak bir sisteme sahip olması gerektiği anlamına gelmektedir (Ceylan, 2007:220). Dolayısıyla denetim kalitesi, finansal tablolardaki önemli yanlışlıkların tespiti ve bu yanlışlıkların raporlanması ile ilgilidir. Tespit edilen bu yanlışlıkların raporlanabilmesi de denetçinin bağımsızlığına bağlıdır (DeAngelo, 1981: 186). Aslanoğlu ve Baskan (2016) göre, denetçinin bağımsızlığı denetim kalitesini yüksek oranda arttırmaktadır. Kaliteli denetimin başlıca koşullarından biri de denetçinin bağımsız, tarafsız ve dürüst davranmasidır (Aslanoğlu ve Baskan: 2016: 77). 


\section{LITERATÜR TARAMASI}

Denetimde zorunlu rotasyonun denetçi bağımsızlığını ve denetim kalitesini sağlamada literatürde çok çeşitli görüşler yer almaktadır. Yapılan bazı araştırmalar rotasyonun denetçi bağımsızlı̆ı ve denetim kalitesini arttırdığını desteklerken; bazı araştırmalarda ise, rotasyonun denetim kalitesiyle doğrudan ilişkisinin olmadığ 1 ve denetim kalitesini olumsuz yönde etkilediği bulgularına ulaşılmaktadır (Şavlı, 2016: 40). Denetimde rotasyon uygulaması ile ilgili yapılan çalışmalar aşağıdaki gibi özetlenebilir.

Salleh ve Jasmani (2014) göre denetçi-müşteri arasındaki uzun süreli iş ilişkisi denetçinin bağımsızlığını olumsuz etkilemektedir. Uzun süreli iş ilişsisi denetçinin profesyonel bakış açısının yok olmasına, küȩük yanlışlıkları göz ardı etmesine ve müşterilerin kendi lehine raporlama baskılarına direnme eğilimlerinin azalmasına neden olmaktadır.

Dopuch vd. (2001) yaptığı çalışmada denetim firması sözleşme süresi ile hatalı finansal raporlama arasındaki ilişkiyi incelemiş ve sonuç olarak maliyetlerin daha hassas düzenlenmesi şartı ile zorunlu rotasyonun denetçinin yönetim lehine raporlama istekliliğini azaltarak bağımsızlığını arttırdığı sonucuna ulaşmış̧ır (Dopuch vd., 2001: 95-116). Buna karşın Barbadillo vd. (2009) rotasyonun denetçi bağımsızlığı üzerine etkisini incelemiş ve rotasyonun denetçi bağımsızlığı açısından finansal raporlar üzerinde bir etkisinin olmadığı sonucuna ulaşmıştır (Barbadillo vd., 2009: 2-26).

Denetimde zorunlu rotasyonu destekleyenler denetçinin gerçekte bağımsızlı̆̆ arttırmasının yanı sıra görünüşte bağımsızlığı da olumlu etkilediğini ileri sürmektedir. Finansal tablolarla ilgilenen taraflar zorunlu rotasyon sistemi uygulanmışsa denetçinin daha bağımsız olacağını düşünmektedir (Doğan, 2016: 5).

Said ve Khasharmes (2014) çalışmalarında zorunlu denetim firması rotasyonunun denetim kalitesi üzerine etkisini incelemiş ve uzun süreli denetim hizmetinin denetçinin performansını düşürdüğü ve rotasyonun denetim kalitesine olumlu etkisinin olduğu sonucuna ulaşmışlardır (Said ve Khasharmes, 2014b: 438). Vitalis vd. (2017) çalışmasında denetçi bağımsızlı̆̆ ile denetim kalitesi arasında güçlü bir ilişkinin olduğu ayrıca denetçinin görev süresinin bağımsızlı̆̆ını tehdit eden faktörlerden biri olduğu sonucuna ulaşmıştır (Vitalis vd. 2017: 57).

Firth vd. (2012) yaptıkları çalışmada rotasyonun müşteri hesaplarını değerlendirmede yeni bir bakış açısı sağlayacağından denetim hatası riskinin azalacağı ve böylece denetim kalitesinin artacağını ileri sürmüşlerdir (Firth vd., 2012: 110). Simmons vd. (2009) göre rotasyonun yapıldı̆̆ ilk yılda denetim bulguları ve hazırlanan raporların kalitesi artmaktadır (Simmons vd., 2009: 123-132). Arel vd., (2005) rotasyon uygulamasının ilk yillarında yapılan denetimlerin kalitesinin düşük olduğunu iddia etmektedir (Arel vd., 2005: 39).

Denetim kalitesinin denetçinin müşterisi ile ilgili bilgi birikimine bağlı olduğu, bu bilgiye de belli bir zaman geçtikten sonra ulaşılabilmektedir. Rotasyon uygulaması ile denetçinin müşterisi ile ilgili bilgi birikiminin kaybolacağı, müşteri işletme ile ilgili daha etkin planlamaların yapılabilmesi ve denetim hatalarının azaltılarak denetim kalitesinin arttırılmasının denetim süresinin arttırılması ile sağlanabileceği ileri sürülmektedir (Tuan, 2015: 298). Daugherty vd. (2012) yapmış olduğu çalışmada rotasyonun bağımsızlı̆̆ı 
arttırmasına karşın rotasyon uygulaması ve müşteriye geri dönme süresinin uzun olmasının müşteri ile ilgili bilgi birikiminin kaybolmasına neden olduğu, rotasyonun denetçilerin iş̧ yükünü arttırdı̆̆ , denetim kalitesine dolaylı, olumsuz etkilerinin olduğu ve istenmeyen sonuçlara neden olabileceği sonucuna ulaşmıştır. Denetçilerin müşteri işletmenin kilit yöneticileri ile ilişki kurabilmenin birkaç yıl geçmesine bağlı olduğu, bu ilişkilerin müşteriyi tanıma ve müşteri risklerini tanımlayarak bunları ele almak amacıyla denetim yaklaşımlarının belirlemesinin önemi vurgulanmakta ve uzun süreli denetim hizmetlerinin denetim kalitesini arttırdığı ileri sürülmektedir (Daugherty vd., 2012: 97-111). Siregar vd. (2012)'de uzun süreli denetimlerin denetim kalitesini arttırdığını iddia etmektedir (Siregar vd., 2012: 70).

Magolis vd. (2011) çalışmasında denetim firmalarının rotasyon süresi yaklaştığında performanslarını azaltarak ücretlerini arttıracakları sonucuna ulaşmıştır (Magolis vd., 2011: 17-18). Bu da denetim kalitesinin düşmesine neden olacaktır.

Diğer yandan rotasyon uygulamasının piyasa rekabetini arttırarak küçük denetim firmalarının piyasaya girmelerini kolaylaştıracağı ileri sürülmektedir. Ancak buna karşın rotasyonun büyük şirketlerin denetim firmalarını değiştirirken büyük denetim firmalarına yönelmesi sonucu yüksek piyasa yoğunlaşmasına neden olacak ve bu durum küçük denetim firmalarını olumsuz etkileyecektir (Doğan, 2016: 5-7).

\section{ARAŞTIRMA YÖNTEMI}

\subsection{Araştırmanın Amacı ve Kısıtlar}

Araştırmanın temel amacı, denetçilerin algılarına göre rotasyonun denetçi bağımsızlığı ve denetim kalitesine etkisini tespit etmektir. Araştırmanın bir diğer amacı ise rotasyon ile denetim kalitesi arasındaki ilişkide denetçi bağımsızlığının aracı rolünü belirlemektir.

Araştırmanın kısıtları, her anket çalışmasında olduğu gibi bu araştırmada da verileri toplamak amaciyla kullanılan anket formuna katılımcıların eksik veya hatalı cevaplar verebilecek olmalarıdır.

\subsection{Araştırma Modeli}

Araştırma kapsamında kullanılan model Şekil 1'de gösterilmektedir.

Şekil 1. Araştırma Modeli

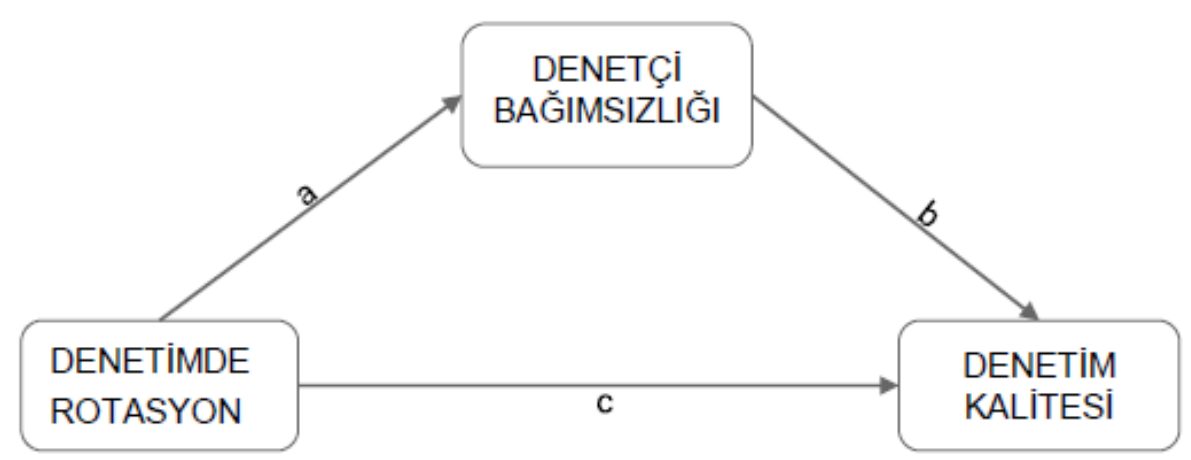




\subsection{Araştırmanın Evreni Ve Örneklemi}

Araştırmanın evrenini 16. 12. 2018 tarihi itibariyle KGK tarafından yetkilendirilen 269 bağımsız denetim firmasında çalışan toplamda 3.707 bağımsız denetçi oluşturmaktadır. Toplam 500 denetçiye ulaşılmış ve geri dönen anket sayısı 311 olup bunların 5 tanesi eksik ya da boş bırakıldıkları için değerlendirmeye alınmamış̧ır. Geriye kalan 306 anket değerlemeye alınmıştır. Kurtuluş (2016); Yazıcıŏlu ve Erdoğan (2007)'na göre örneklem sayısı, \% 95 güven aralığı ve $\% 5$ anlamlılık düzeyinde yeterli kabul edilmektedir.

\subsection{Anket Formunun Hazırlanması Ve Veri Toplama Yöntemi}

Araştırmada veri toplama aracı olarak anket formu kullanılmıştır. Araştırmada kullanılan anket formu iki bölümden oluşmaktadır. Birinci bölüm denetçilerin demografik bilgilerini içermektedir. İkinci bölümde ise, bağımsız denetçilerin denetimde rotasyon, denetçi bağımsızlığı ve denetim kalitesine ilişkin algılarını tespit etmek amacıyla literatürdeki ölçeklerden yararlanılarak oluşturulan üç değişkenli 5'li likert tipi sorular yer almaktadır. Ölçekler Türkçeye uyarlanmıştır. Anketin son kısmında denetçilerin rotasyon hakkındaki genel düşüncelerini belirlemek amacı ile açı uçlu bir soru yöneltilmiştir. Anket soruları alanında uzman akademisyen ve bağımsız denetçilere inceletilerek gerekli düzeltmeler yapılmış, pilot bir uygulama yapıldıktan sonra ankete son şekli verilmiştir. Araştırmada kullanılan ölçekler, kodları ve yararlanılan kaynaklar Tablo 1' gösterilmiştir.

Tablo 1. Araştırmada Kullanılan Ölçekler

\begin{tabular}{|c|l|l|}
\hline \multicolumn{1}{|c|}{ Ölçek } & \multicolumn{1}{|c|}{ Kod } & \multicolumn{1}{c|}{ Yararlanılan Kaynak } \\
\hline Denetimde Rotasyon Algıs1 & $\mathrm{r} 24, \mathrm{r} 25, \mathrm{r} 26, \mathrm{r} 27, \mathrm{r} 28$ & $\begin{array}{l}\text { J1an, Shi, Ying, Li, \& Chiang, } \\
(2012)\end{array}$ \\
\hline Denetçi Bağımsızlı̆ğ Alg1s1 & $\begin{array}{l}\mathrm{b} 29, \mathrm{~b} 30, \mathrm{~b} 31, \mathrm{~b} 32, \mathrm{~b} 33, \mathrm{~b} 34, \mathrm{~b} 35, \\
\mathrm{~b} 26, \mathrm{~b} 37, \mathrm{~b} 38, \mathrm{~b} 39\end{array}$ & Said \& Khasharmeh (2014a) \\
\hline Denetim Kalitesi Algıs1 & $\begin{array}{l}\mathrm{k} 1, \mathrm{k} 2, \mathrm{k} 3, \mathrm{k} 4, \mathrm{k} 5, \mathrm{k} 6, \mathrm{k} 7, \mathrm{k} 8, \mathrm{k} 9, \\
\mathrm{k} 10, \mathrm{k} 11, \mathrm{k} 12, \mathrm{k} 13, \mathrm{k} 14, \mathrm{k} 15, \mathrm{k} 16, \\
\mathrm{k} 17, \mathrm{k} 18, \mathrm{k} 19, \mathrm{k} 20, \mathrm{k} 21, \mathrm{k} 22, \mathrm{k} 23\end{array}$ & $\begin{array}{l}\text { Olowookere \& Adebiyi (2013) ve } \\
\text { Said \& Khasharmeh (2014b) }\end{array}$ \\
\hline
\end{tabular}

\subsection{Araştırmada Kullanılan İstatistiki Yöntemler}

Araştırmada elde edilen veriler SPSS 22.0 paket programı ile analiz edilmiştir. Bu doğrultuda denetçilerin denetimde rotasyon, denetçi bağımsızlı̆̆ ve denetim kalitesi algılarının belirlenmesi amacıyla geliştirilen ölçeklerin yapı geçerliliği Açımlayıcı Faktör Analizi ile test edilmiştir. Rotasyon algısının denetçi bağımsızlı̆̆ ve denetim kalitesi algısına etkisi ile denetçi bağımsızlı̆ı̆ının denetim kalitesine etkisi Regresyon Analizi ile test edilmiştir. Denetimde rotasyon ile denetim kalitesi arasındaki ilişkide denetçi bağımsızlığının aracı rolünü tespit etmek amacıyla PROCESS 2.15 makro kod kullanılmıştır. Ayrıca denetçilerin demografik değişkenlere göre algı farklılıklarını belirlemek amacı ile de ANOVA 
ve Bağımsız İki Örneklem t Testi analizleri uygulanmıştır. İstatistiksel değerlendirmeler ölçekte yer alan ifadelerin ortalamaları hesaplanarak bu puanlar üzerinden yapılmıştır.

\subsection{Araştırma Bulguları}

Verileri analiz etmeden önce ölçeklerin normal dağılıp dağılmadığını tespit etmek amacıyla değişkenlerin çarpıklık (skewness) ve basıklık (kurtosis) değerlerine bakılmış ve ölçeklerin çarpıklık ve basıklık değerlerinin $-1,96$ ve 1,96 arasında olduğu görülmüş̧ür. Çarpıklık ve basıklık değerlerin -1,96 ve 1,96 arasında olması dağılımın normal olduğunu gösterdiğinden (Can, 2013: 84-85) araştırmanın amaçları doğrultusunda parametrik testler uygulanmıştır.

\subsubsection{Demografik Değişkenlere İlişkin Tanımlayıcı İstatistikler} almaktadır.

Denetçilerin demografik değişkenlerine ait frekans ve yüzdeleri Tablo 2'de yer

Tablo 2. Demografik Değişkenlere İlişkin Tanımlayıcı İstatistikler

\begin{tabular}{|c|c|c|c|}
\hline Özellik & Kategori & Frekans (N) & Yüzde \% \\
\hline \multirow{2}{*}{ Cinsiyet } & Kadın & 41 & 13,4 \\
\hline & Erkek & 265 & 86,6 \\
\hline \multirow{5}{*}{ Yaş } & 30 ve alt1 & 27 & 8,8 \\
\hline & $31-40$ & 48 & 15,7 \\
\hline & $41-50$ & 105 & 34,3 \\
\hline & $51-60$ & 89 & 29,1 \\
\hline & 61 ve üstü & 37 & 12,1 \\
\hline \multirow{3}{*}{ Öğrenim Durumu } & Lisans & 226 & 73,9 \\
\hline & Yüksek Lisans & 73 & 23,9 \\
\hline & Doktora & 7 & 2,3 \\
\hline \multirow{2}{*}{ Unvan } & Denetçi & 235 & 76,8 \\
\hline & Sorumlu Denetçi & 71 & 23,2 \\
\hline \multirow{5}{*}{ Aylık Gelir } & 5000 ve altı & 70 & 22,9 \\
\hline & $5001-7000$ & 61 & 19,9 \\
\hline & $7001-9000$ & 38 & 12,4 \\
\hline & $9001-11000$ & 38 & 12,4 \\
\hline & 11000 üzeri & 99 & 32,4 \\
\hline \multirow{5}{*}{ Deneyim } & 5 yıldan az & 88 & 28,8 \\
\hline & $5-10$ & 41 & 13,4 \\
\hline & $10-15$ & 45 & 14,7 \\
\hline & $15-20$ & 38 & 12,4 \\
\hline & 20 yıldan fazla & 94 & 30,7 \\
\hline \multirow{5}{*}{$\begin{array}{c}\text { Kurumda Çalışan } \\
\text { Denetçi Sayısı }\end{array}$} & 5 ve altı & 81 & 26,5 \\
\hline & $6-10$ & 106 & 34,6 \\
\hline & $11-16$ & 42 & 13,7 \\
\hline & $17-21$ & 36 & 11,8 \\
\hline & 22 ve üzeri & 41 & 13,4 \\
\hline Toplam & & 306 & 100 \\
\hline
\end{tabular}


Denetçilerin demografik değişkenlere ait veriler incelendiğinde; araştırmaya katılan denetçilerden \%13,4'ü kadın, \%86,6'sı erkeklerden oluşmaktadır. Denetçilerin yaş aralığına bakıldığında, $\% 75,5$ ile çoğunluğunun 40 yaş üstü olduğu görülmektedir. Araştırmaya katılan denetçilerin \%73,9'unun lisans mezunu; \%76,8'inin denetçi ve \%23,9'unun ise sorumlu denetçi olduğu belirlenmiş̧tir.

Denetçilerin aylık gelirlerine bakıldığında \%22,9'u 5.000 ve altı, \%19,9'u 5.001-7.000 arası, \%12,4'ü 7001-9000 aras1, \%12,4'ü 9.001-11.000 aras1, \%32,4'ü 11.000 üzeri gelir elde ettiklerini ifade etmişlerdir. Denetçilerin \%30,7 ile çoğunluğunun 20 yıldan fazla mesleki deneyime sahip olduğu belirlenmiştir. Denetçilerin bağlı olduğu denetim firmasında çalışan denetçi sayılarına bakıldığında, \%86,6' sının çalıştığı firmadaki denetçi sayısının 22'in altında olduğu tespit edilmiştir.

\subsubsection{Güvenilirlik Analizi Ve Bulgular}

Güvenilirlik bir ölçme aracının tutarlılı̆̆ ile ilgilidir. Farklı güvenilirlik analizi yöntemleri olmakla birlikte bu araştırmada ölçeklerin iç tutarlılı̆ı̆ı belirlemek amacıyla Cronbach alfa katsayısı yöntemi kullanılmıştır. Gürbüz ve Şahin (2016) göre Cronbach alfa katsayısının en az 0,70 olması gerekmektedir. Bu oran ölçek geliştirme çalışmalarında kabul edilebilir değer 0,60’tır (Gürbüz ve Şahin, 2016: 323-325). Ölçeklerin Güvenilirlik analizine iliş̧kin istatistiki bulgular Tablo 3 'te verilmiştir.

Tablo 3. Ölçeğin Güvenilirlik Analizi İstatistiki Bulgular

\begin{tabular}{lcc}
\hline \multicolumn{1}{c}{ Ölçek } & Soru Sayısı & $\begin{array}{c}\text { Güvenilirlik } \\
\text { (Cronbach's Alpha) }\end{array}$ \\
\hline Denetimde Rotasyon Algısı & 5 &, 788 \\
\hline Denetçi Bağımsızlığı Algısı & 11 &, 741 \\
\hline Denetim Kalitesi Algısı & 23 &, 881 \\
\hline
\end{tabular}

Güvenilirlik analizi sonuçlarına göre, denetçilerin denetimde rotasyon, denetçi bağımsızlığı ve denetim kalitesi algılarını belirlemek amacıyla geliştirilen ölçeklerin kabul edilebilir değer olan 0,60 üzeri olduğu tespit edilmiş̧tir. Buna göre ölçekleri oluşturan maddeler arasında iç tutarlılıkların sağlandığı ve ölçeklerin güvenilir olduğu söylenebilir.

\subsection{3. Ölçeklere İliş̧kin Açımlayıcı Faktör Analizi İstatistiki Bulgular}

Açımlayıcı faktör analizi bir biri ile ilişkili olan çok sayıda değişkenlerin birlikte açıklayabildikleri daha az sayıda değişkenler ile anlamlı faktöre ulaşmayı hedeflemektedir. Ölçek geliştirme ya da literatürde mevcut olan ölçeklerde madde ekleme çıkarma yapılması durumunda açımlayıcı faktör analizinin yapılması uygun görülmektedir (Büyüköztürk, 2007: 123). Açımlayıcı faktör analizi uygulayabilmek için ilk olarak verilerin faktör analizi için uygunluğunun tespit edilmesi gerekmektedir. Bunu belirlemek amaciyla KMO (KaiserMeyer-Olkin Measure) ve Barlett Küresellik testi uygulanmalıdır. KMO verilerin yapısının faktör analizi için yeterliliği (ilişskiler anlamında örneklem yeterliliği)'ni göstermektedir. KMO katsayısının 0,70'in üzerinde olması iyi, 0,50 ile 0,70 arasında olması yeterli ve 0,50 'nin altında olması ise yeterli ilişkiyi sağlayacak örneklem ihtiyacını belirtmektedir. 
Barlett Küresellik testi ise, korelasyon matrisindeki ilişkilerin faktör analizi için yeterliliğini göstermektedir. Faktör analizi için değişkenler arası ilişkinin oluşturduğu korelasyon matrisinin anlamlı olması gereklidir. Barlett Küresellik testi p katsayısının 0,05'in altında olması bu matrisin anlamlı olduğunu belirtmektedir (Can, 2013: 277; Gürbüz, 2016: 312$319)$.

Denetimde rotasyon algısı ölçeğinin açımlayıcı faktör analizi sonucu elde edilen bulgular Tablo 4'te gösterilmiştir.

Tablo 4. Denetimde Rotasyon Algısı Ölçeğinin Açımlayıcı Faktör Analizi İstatistiki Bulgular

\begin{tabular}{|c|c|c|c|}
\hline Maddeler & Faktör Yükleri & $\begin{array}{l}\text { Açıklanan Toplam } \\
\text { Varyans (\%) }\end{array}$ & $\begin{array}{c}\text { Güvenilirlik } \\
\text { (Cronbach's Alpha) }\end{array}$ \\
\hline $\mathrm{r} 24$ & ,776 & \multirow{5}{*}{54,200} & \multirow{6}{*}{, 788} \\
\hline $\mathrm{r} 25$ & ,768 & & \\
\hline $\mathrm{r} 26$ &, 755 & & \\
\hline $\mathrm{r} 27$ & ,700 & & \\
\hline $\mathrm{r} 28$ & 677 & & \\
\hline KMO: ,727 & $\mathbf{p}=0,000$ & & \\
\hline
\end{tabular}

Tablo 4 incelendiğinde, denetimde rotasyon algısı ölçeğinin KMO katsayısının ,727 olması örneklem büyüklüğünün yeterli olduğunu göstermektedir. Barlet Testi sonucunun anlamlı olduğu tespit edilmiş $(\mathrm{p}<0,05)$ ve buna göre değişkenler arasındaki korelasyon ilişkisinin yeterli olduğu sonucuna ulaş1lmıştır.

Ölçme aracını oluşturan 5 maddenin toplam varyansın \%54'ünü açıkladığı tespit edilmiştir. Bu oran; Tavşancıl (2010)'a göre \%40 üzeri, Büyüköztürk (2007)'e göre tek faktörlü ölçeklerde \%30 ve üzeri kabul edilmektedir (Tavşancıl, 2010: 48; Büyüköztürk, 2007: 125).

Denetim de rotasyon algısı ölçeğini oluşturan her bir maddenin faktör yükünün 0,60 '`n üstünde olduğu tespit edilmiştir. Örneklem sayısının 150'den fazla olduğu durumlarda faktör yük değerinin 0,40 üzerinde olması kabul edilebilmektedir (Field, 2013: 684). Bu bulgulara göre 5 maddeden oluşan denetimde rotasyon algısı ölçeğinin yapısının geçerli olduğu söylenebilir.

Denetçi bağımsızlığı algısı ölçeğinin açımlayıcı faktör analizi istatistiki bulguları Tablo 5 'te yer almaktadır.

Tablo 5 incelendiğinde, denetçi bağımsızlığı algısı ölçeğinin KMO katsayısının ,796 olduğu tespit edilmiş ve buna göre örneklem büyüklüğünün yeterli ve verilerin faktör analizi için uygun olduğu sonucuna ulaşılmıştır. Barlet Testi sonucunun anlamlı olduğu belirlenmiş $(p<0,05)$ ve buna göre değişkenler arasındaki korelasyon ilişkisinin yeterli olduğu sonucuna ulaşılmıştır. 
Tablo 5. Denetçi Bağımsızlığı Algısı Ölçeğinin Açımlayıcı Faktör Analizi İstatistiki Bulgular

\begin{tabular}{cccc}
\hline Maddeler & Faktör Yükleri & $\begin{array}{c}\text { Açıklanan Toplam } \\
\text { Varyans (\%) }\end{array}$ & $\begin{array}{c}\text { Güvenilirlik } \\
\text { (Cronbach's Alpha) }\end{array}$ \\
\hline b30 &, 654 & & \\
\cline { 1 - 2 } b31 &, 671 & & \multirow{2}{*}{,796 } \\
\hline b32 &, 771 & 49,629 & \\
\hline b33 &, 739 & & \\
\hline b34 &, 692 & \\
\hline b36 &, 693 & & \\
\hline KMO:, 788 & Barlett Testi: $\mathbf{p}=0,000$ & & \\
\hline
\end{tabular}

Açımlayıcı faktör analizi sonucu, denetçilerin bağımsızlık algılarını belirlemek amacıyla 11 maddeden oluşturulan denetçi bağımsızlığı ölçeğinden b29, b35, b37, b38, b39 kodlu maddeler açıklanan varyansa katkılarının ve faktör yüklerinin düşük olması nedeniyle ölçekten çıkarılmıştır. Yeniden yapılan faktör analizi sonucu, her bir maddenin faktör yük değerinin 0,60 üzerinde olduğu ve 6 maddenin toplam varyansın yaklaşık \%50'sini açıkladığı belirlenmiştir. Açıklanan toplam varyansın Büyüköztürk (2007) göre tek faktörlü ölçeklerde kabul edilebilir değer olan \% 30'un üzerinde olduğu görülmektedir (Büyüköztürk, 2007: 125). Ayrıca ölçekten çıkarılan maddelerden sonra 6 maddeden oluşan ölçeğin güvenilirlik katsayısının ,741'den ,796'ya yükseldiği tespit edilmiştir. Bu bulgular denetçi bağımsızlığı algısı ölçeğinin yapısının geçerli olduğunu göstermektedir.

Denetim kalitesi ölçeğinin açımlayıcı faktör analizi istatistiki bulguları Tablo 6'da yer almaktadır.

Tablo 6. Denetim Kalitesi Algısı Ölçeğinin Açımlayıcı Faktör Analizi İstatistiki Bulgular

\begin{tabular}{|c|c|c|c|}
\hline Maddeler & Faktör Yükleri & $\begin{array}{c}\text { Açıklanan Toplam } \\
\text { Varyans (\%) }\end{array}$ & $\begin{array}{c}\text { Güvenilirlik } \\
\text { (Cronbach's Alpha) }\end{array}$ \\
\hline $\mathrm{k} 1$ & ,677 & \multirow{14}{*}{51,775} & \multirow{14}{*}{ 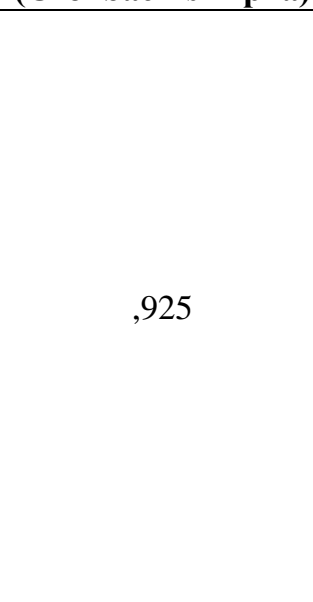 } \\
\hline $\mathrm{k} 2$ & ,784 & & \\
\hline $\mathrm{k} 3$ & 812 & & \\
\hline $\mathrm{k} 4$ & 830 & & \\
\hline k5 & 828 & & \\
\hline k6 & 804 & & \\
\hline k7 & 802 & & \\
\hline $\mathrm{k} 8$ & ,833 & & \\
\hline k9 & ,799 & & \\
\hline $\mathrm{k} 15$ &, 549 & & \\
\hline k18 & ,600 & & \\
\hline $\mathrm{k} 20$ & ,518 & & \\
\hline $\mathrm{k} 21$ & ,604 & & \\
\hline $\mathrm{k} 22$ & 478 & & \\
\hline
\end{tabular}


Tablo 6'ya bakıldığında, KMO katsayısının ,925 ve Barlett testi sonucunun anlamlı $(p<0,05)$ olduğu tespit edilmiştir. Buna göre örneklem büyüklüğünün ve değişkenler arasındaki ilişsinin oluşturduğu korelasyon matrisinin faktör analizi uygulayabilmek için uygun olduğu belirlenmiştir.

Faktör analizi sonucu, denetim kalitesi algısı ölçeğinden k10, k11, k12, k13, k14, k16, k17, k19, k23 kodlu değişkenlerin açıklanan varyansa katkılarının ve faktör yüklerinin düşük olması nedeniyle ölçekten çıkarılmıştır. Yeniden yapılan faktör analizi sonucu, ölçeği oluşturan her bir maddenin faktör yük değerinin 0,47 üzerinde olduğu ve bu oranın Tavşancıl (2010) göre kabul edilebilir değer olan 0, 40'ın üzerinde olduğu tespit edilmiştir (Tavşancıl, 2010: 48). Yine ölçeğe ait 14 maddenin toplam varyansın \%52'sini açıkladığ 1 belirlenmiştir. Ayrıca ölçekten çıkarılan maddelerden sonra yapılan güvenilirlik analizi sonucu 14 maddelik ölçeğin güvenilirlik katsayısının ,881'den ,925'e yükseldiği tespit edilmiştir. Buna göre denetçilerin denetim kalitesi algılarını ölçmek amacıyla geliştirilen ölçeğin yapınsın geçerli olduğu söylenebilir.

\subsubsection{Korelasyon Analizi İstatistiki Bulgular}

Denetimde rotasyon algısı, denetçi bağımsızlı̆̆ı algısı ve denetim kalitesi algısı değişkenleri arasındaki ilişkinin belirlenmesi amacıyla çoklu korelasyon analizi yapılmıştır. Araştırma sonucunda elde edilen verilerin normal dağıldıkları göz önünde bulundurularak Pearson Korelasyon Analizi uygulanmıştır. Analiz sonucu Tablo 7'de gösterilmiştir.

Tablo 7. Korelasyon Analizi İstatistiki Bulgular

\begin{tabular}{lccc}
\hline \multicolumn{1}{c}{ Değişkenler } & $\begin{array}{c}\text { Denetimde } \\
\text { Rotasyon } \\
\text { Algısı }\end{array}$ & $\begin{array}{c}\text { Denetçi } \\
\text { Bağımsızlığı } \\
\text { Algısı }\end{array}$ & $\begin{array}{c}\text { Denetim } \\
\text { Kalitesi } \\
\text { Algısı }\end{array}$ \\
\hline Denetimde Rotasyon Algısı & - & & \\
\hline Denetçi Bağımsızlığı Algısı &, $350^{* *}$ & - & - \\
\hline Denetim Kalitesi Algısı &, $336^{* *}$ &, $552 * *$ & \\
\hline$* * \mathrm{p}<0,01$ & & & \\
\hline
\end{tabular}

Tablo 7 incelendiğinde, analiz sonucu elde edilen bulgular denetimde rotasyon algis1, denetçi bağımsızlığı algısı ve denetim kalitesi algısı arasında anlamlı, pozitif yönlü ve güçlü bir ilişkinin olduğunu göstermektedir.

\subsubsection{Regresyon Analizi İstatistiki Bulgular}

Regresyon analizi, bağımlı değişken üzerinde etkisi olduğu düşünülen bağımsız değişken veya değişkenler arasındaki neden-sonuç ilişkisinin bir modelle açıklanmasını ifade etmektedir (Gürbüz ve Şahin, 2016: 271). Denetimde rotasyon algısının denetçi bağımsızlığ algısına ve denetim kalitesi algısına etkisi ile denetçi bağımsızlı̆̆ı algısının denetim kalitesi 
algısına etkisi Basit Regresyon Analizi ile test edilmiştir. Analiz sonuçları Tablo 8'de gösterilmiştir.

Tablo 8. Regresyon Analizi İstatistiki Bulgular

\begin{tabular}{|c|c|c|c|c|}
\hline \multirow{2}{*}{ Model } & \multicolumn{3}{|c|}{ Regresyon Katsayıları } & \multirow{2}{*}{$\begin{array}{c}\text { Model } \\
\text { İstatistikler }\end{array}$} \\
\hline & Beta $(\beta)$ & Std. Hata & $\mathbf{P}$ & \\
\hline $\begin{array}{c}\text { 1.Rotasyon Algısının } \\
\text { Denetçi Bağımsızlığı Algısına } \\
\text { Etkisi }\end{array}$ &, 350 & 053 &, 000 & $\begin{array}{l}\mathrm{R}^{2}:, 122 \\
\text { Adj. } \mathrm{R}^{2}:, 120 \\
\mathrm{~F}: \quad 42,416 \\
\mathrm{p}: \quad, 000<, 001\end{array}$ \\
\hline $\begin{array}{l}\text { 2.Denetçi Bağımsızlı̆̆ Algısının } \\
\text { Denetim Kalitesi Algısına Etkisi }\end{array}$ &, 552 &, 050 &, 000 & $\begin{array}{l}\mathrm{R}^{2}:, 304 \\
\text { Adj. } \mathrm{R}^{2}:, 302 \\
\mathrm{~F}: \quad 133,031 \\
\mathrm{p}: \quad, 000<, 001\end{array}$ \\
\hline $\begin{array}{c}\text { 3.Rotasyon Algısının } \\
\text { Denetim Kalitesi Algısına } \\
\text { Etkisi }\end{array}$ & ,336 &, 056 &, 000 & $\begin{array}{l}\mathrm{R}^{2}:, 113 \\
\text { Adj. } \mathrm{R}^{2}: 110 \\
\mathrm{~F}: \quad 38,748 \\
\mathrm{p}: \quad, 000<, 001\end{array}$ \\
\hline
\end{tabular}

Tablo 8'de gösterilen 1. modelin istatistiki değerleri ne bakıldığında, rotasyon algısının denetçi bağımsızlığı algısı ile kurulan regresyon modelinin anlamlı olduğu tespit edilmiştir $(\mathrm{p}=0,000)$. Regresyon katsayıları incelendiğinde denetimde rotasyon algısının denetçi bağımsızlığı algısına anlamlı ve pozitif yönlü bir etkisi olduğu saptanmıştır $(p<0,01$; $\beta=, 350$ ). Buna göre denetimde rotasyon algısındaki bir birimlik artış denetçi bağımsızlığ algısını 0,350 birim arttıracaktır.

Model 2 incelendiğinde, model istatistiklerine göre modelin anlamlı olduğu sonucuna ulaşılmıştır $(\mathrm{p}=0,000)$. Ayrıca regresyon katsayıları değerlendirildiğinde denetçi bağımsızlı̆̆ algısının denetim kalitesi algısına anlamlı ve pozitif yönlü bir etkisi olduğu tespit edilmiştir $(p<0,01 ; \beta=, 552)$. Buna göre denetçi bağımsızlığı algısındaki bir birimlik artış denetim kalitesi algisını 0,552 birim arttıracaktır.

Model 3 incelendiğinde, modelin anlamlı olduğu tespit edilmiştir $(p=0,000)$. Ayrıca regresyon katsayıları incelendiğinde denetimde rotasyon algısının denetim kalitesi algısına etkisinin anlamlı ve pozitif yönlü olduğu tespit edilmiştir $(p<0,01 ; \beta=, 336)$. Buna göre denetimde rotasyon algısındaki bir birimlik artış denetim kalitesi algısını 0,336 birim arttıracaktır.

\subsubsection{Aracılık Testi İstatistiki Bulgular}

Bağımsız değişkenin bağımlı değişkene etkisini ileten değişken aracı değişken olarak tanımlanmaktadır. Müdahaleci değişken olarak da adlandırılabilir. Aracı değişken bağımlı değişkenin bağımsız değişken üzerindeki etkisini açıklamaya yardımcı olan değişkendir. Aracı değişken, bağımlı ve bağımsız değişken arasında bağlantı mekanizması gibi çalışmaktadır. Aracı değişken bağımsız değişken etkisiyle bağımlı değişkeni etkilemektedir (Gürbüz ve Şahin, 2016: 81). Baron ve Kenny (1986)'ye göre arac1lik testinin 
uygulanabilmesi için aşağıda belirtilen kriterlerin sağlanması gerekmektedir (Baron ve Kenny, 1986: 1175-1177).

1. Bağımsız değişkenin, aracı değişken üzerinde istatistiksel olarak anlamlı bir etkisi olmalıdır.

2. Aracı değişkenin bağımlı değişken üzerinde istatistiksel olarak anlamlı bir etkisi olmalıdır.

3. Bağımsız değişkenin, bağımlı değişken üzerinde istatistiksel olarak anlamlı bir etkisi olmalıdır.

4. Aracı değişken ile bağımsız değişken birlikte modele dâhil edildiğinde, bağımsız değiş̧keninin bağımlı değişken üzerindeki etkisi sıfır olmalı veya azalmalıdır. Bağımlı değişkenin bağımsız değişken üzerindeki etkinin azalması durumunda kısmi aracılık, etkinin sıfır olması durumunda tam aracılıktan söz edilebilir.

Yukarıda belirtilen ilk üç kriter Tablo 8'de belirtilen regresyon analizi sonucu sağlandığı görülmektedir. Son kriter ise Hayes (2013) tarafından geliştirilen, Baron ve Kenny (1986) yöntemine dayanan makro kod (PROCESS 2.15) ile test edilmiştir. Analiz sonuçları istatistiki bulgular Tablo 9'da yer almaktadır.

Tablo 9. Denetimde Rotasyon Algısı ile Denetim Kalitesi Algısı Arasındaki İlişkide Denetçi Bağımsızlığı Algısının Aracılık Etkisi İstatistiki Bulgular

\begin{tabular}{|c|c|c|c|c|c|}
\hline & Beta & Std.Hata & $P$ & \multicolumn{2}{|c|}{$\begin{array}{c}\text { Model } \\
\text { İstatistikleri }\end{array}$} \\
\hline Bağımsızlık &, 513 &, 052 &, 000 & \multirow{2}{*}{\multicolumn{2}{|c|}{$\begin{array}{r}\mathrm{R}^{2}:, 328 \quad \mathrm{~F}: 73,865 \\
\mathrm{p}:, 000<, 001\end{array}$}} \\
\hline Rotasyon & ,168 & 052 & ,001 & & \\
\hline Rotasyon $\rightarrow$ Bağımsızlık & ,347 & ,053 &, 000 & \multicolumn{2}{|c|}{$\begin{array}{l}\mathrm{R}^{2}:, 122 \mathrm{~F}: 42,416 \\
\mathrm{p}: \quad, 000<, 001\end{array}$} \\
\hline $\begin{array}{l}\text { Denetçi Bağımsızlığııın } \\
\text { Aracı Etki Olduğu İlişski }\end{array}$ & $\begin{array}{l}\text { Toplam } \\
\text { Etki }\end{array}$ & $\begin{array}{c}\text { Doğrudan } \\
\text { Etki }\end{array}$ & $\begin{array}{c}\text { Dolaylı } \\
\text { Etki }\end{array}$ & $\begin{array}{c}\text { Bootstrap Güven } \\
\text { Aralığı } \\
\text { (BoLLCI-BoULCI) }\end{array}$ & $\begin{array}{l}\text { Aracı } \\
\text { Etki } \\
\text { Türü }\end{array}$ \\
\hline Rotasyon $\rightarrow$ Kalite & ,346 & , 168 & ,178 & $(, 0912)-(, 2863)$ & Kısmi \\
\hline Sobel Testi: $\quad z=5,411$ & 000 & & & & \\
\hline
\end{tabular}

Tablo 9 incelendiğinde, denetimde rotasyon algısı ile denetim kalitesi algısı arasındaki ilişkide denetçi bağımsızlığı algısının kısmi aracılık etkisi olduğu tespit edilmiştir. Ancak aracılık etkisinden tam olarak söz edebilmek için bu etkinin anlamllı̆̆̆ Sobel Testi z sonucu ve Bootstrap güven aralığı sonuçlarına da bakılması gerekmektedir. Bu anlamlılık z skorunun 1,96'dan büyük ve anlamlı olması ve Bootstrap güven aralığının (BoLLCI-BoULCI) sıfir değerini içermemesi gerekir (Preacher ve Hayes, 2004: 718; Preacher ve Hayes, 2008: 883887). Tablo 9'da verilen sonuçlar incelendiğinde Sobel testi z skorunun anlamlı olduğu $(\mathrm{z}=5,411 ; \mathrm{p}=0,000)$ ayrıca Bootsrap güven aralığının sıfır değerini içermediği görülmektedir. Sonuçlar genel olarak değerlendirildiğinde, denetimde rotasyon algısının denetim kalitesi 
algısına aracılık (dolaylı) etkisinin (,178) olduğu tespit edilmiştir. Ancak denetimde rotasyon algısının denetim kalitesi algısına doğrudan etkisinin $(, 168)$ olduğu da göz ardı edilmemelidir.

Araştırma modeli sonucu Şekil 2'de gösterilmiştir.

Şekil 2. Araştırma Modeli Sonucu

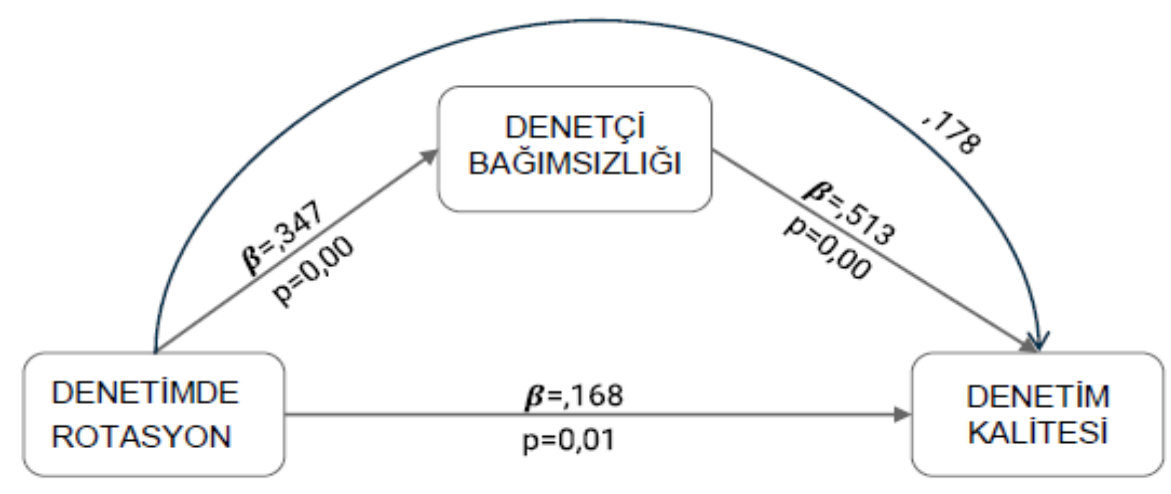

Denetçilerin algılarından elde edilen bu bulgular denetimde rotasyonun denetçi bağımsızlığını arttırarak denetim kalitesini dolaylı olarak arttırdığını göstermekte ancak denetimde rotasyonun denetim kalitesini doğrudan arttırdı̆̆ da görülmektedir. Buna göre denetçiler denetimde rotasyon sistemi ile hizmetlerinde daha bağımsız olacak ve böylece denetim kalitesi artacaktır. Ayrıca denetimde rotasyon ile denetime getirilecek yeni bir bakış açısı denetim kalitesini doğrudan arttıracaktır.

\subsubsection{Fark Analizi İstatistiki Bulgular}

Denetçilerin demografik değişkenlere göre algı farlılıklarını belirlemek amacıyla Bağımsız İki Örneklem t Testi ve ANOVA Testi uygulanmışıtı. Bu doğrultuda bağımsız iki grubun belirli değişkenlere ait algılarında fark olup olmadığı Bağımsız İki Örneklem t Testi ile, ikiden fazla olan grupların algılarında fark olup olmadığı ANOVA Testi ile analiz edilmiştir. Analiz sonuçları aşağıda Tablo 10'da verilmiştir.

Tablo 10. Demografik Değişkenlere İlişkin Fark Analizi İstatistiki Bulgular

\begin{tabular}{|c|c|c|c|c|c|c|c|}
\hline $\begin{array}{l}\text { Demografik } \\
\text { Değişken }\end{array}$ & Cinsiyet & Unvan & Yaş & $\begin{array}{l}\text { Öğrenim } \\
\text { Durumu }\end{array}$ & $\begin{array}{l}\text { Aylık } \\
\text { Gelir }\end{array}$ & Deneyim & $\begin{array}{c}\text { Firmada } \\
\text { Çalışan Denetçi } \\
\text { Sayısı } \\
\end{array}$ \\
\hline Ölçek & $\mathbf{p}$ & $\mathbf{p}$ & $\mathbf{p}$ & $\mathbf{p}$ & $\mathbf{p}$ & $\mathbf{P}$ & $\mathbf{p}$ \\
\hline $\begin{array}{c}\text { Denetimde } \\
\text { Rotasyon } \\
\text { Algisı } \\
\end{array}$ & ,678 & 484, & 431 & ,182 & ,830 & 191, & 223 \\
\hline $\begin{array}{c}\text { Denetçi } \\
\text { Bağımsızlı̆ı } \\
\text { Algısı } \\
\end{array}$ & ,897 & ,359 & ,524 & ,448 & ,489 & , 430 & ,793 \\
\hline $\begin{array}{c}\text { Denetim } \\
\text { Kalitesi } \\
\text { Algısı } \\
\end{array}$ & ,603 & ,072 & ,738 & 965, & ,519 & , 100 & ,873 \\
\hline
\end{tabular}


Tablo 10 incelendiğinde, fark analizleri sonucu anlamlllık oranının (p) 0,05 'ten büyük olduğu saptanmıştır. Buna göre denetçilerin demografik değiş̧enlere göre denetimde rotasyon, denetçi bağımsızlığı ve denetim kalitesine ilişkin algılarında fark olmadığı tespit edilmiştir. Diğer bir ifadeyle, araştırmaya katılanların demografik özelliklerinin, denetimde rotasyon, denetçi bağımsızlığı ve denetim kalitesine ilişkin algılarında her hangi bir değişikliğe neden olmadığı tespit edilmiştir.

\subsubsection{Denetçilerin Rotasyona İlişkin Genel Görüşlerinin Değerlendirilmesi}

Çalışmanın bu kısmında araştırmaya katılan denetçilerin anket formunda yer alan açık uçlu soruya verdikleri yanttlar ile denetçilerle yapılan yüz yüze görüşmelerden elden edilen bilgiler değerlendirilmiştir. Buna göre;

Denetçiler denetimde rotasyon uygulaması ile denetimin daha etkin ve verimli kılınarak daha faydalı denetim raporları üretilebileceğini,

Rotasyon uygulamasının denetçi bağımsızlığını arttırdığı görüşüne karşın denetimde rotasyon uygulaması denetçiye olan güvensizliğin belirtisi olarak da değerlendirilebileceğini,

Denetçiler denetim kalitesi sağlamada denetçinin yetkinliği, müşteri işletmenin iç dinamiklerini bilmesi ve sektörü tanımasının daha etkin olabileceğini,

Denetim kalitesinin kaliteli denetçiler ve denetim firmaları ile sağlanabileceğini, bununda denetçi olabilmek için daha nitelikli sınavların yapılması ve sürekli eğitim programları ile mümkün olabileceğini düşünmektedirler.

Tüm bu görüşlerin yanı sıra bir diğer önemli görüş ise denetim ücretlerinin müşteri firmadan sağlanması nedeniyle denetçilerin tam bağımsızlığının sağlanamayacağı ve büyük denetim firmalarının kendi bünyelerinde kurdukları ya da danışıklı firmalarla müşterilerini değiştirmeleri yoluyla rotasyonu aşmalarıdır. Bu durumun da küçük denetim firmalarının piyasaya girmelerini zorlaştırdığını ve dolayısıyla rotasyondan beklenen faydaları ortadan kaldırdı̆̆ını düşünmektedirler.

\section{SONUÇ VE DEĞERLENDİRME}

Bağımsız denetim, işletmelerin hazırlamış oldukları finansal tabloların doğruluğu ve güvenilirliği konusunda bilgi kullanıcılarına makul düzeyde güvence sağlamaktadır. Bu güven denetçinin bağımsızlı̆̆ ve denetim kalitesi ile sağlanabilmektedir. Ancak 2000'li yıllarda yaşanan finansal skandallar bağımsız denetime olan güveni sarsmıştır. $\mathrm{Bu}$ durumun oluşmasına neden olan etkenlerden biri de denetçinin hizmetlerinde bağımsız olarak hareket etmemesi ve düşük denetim kalitesi olarak görülmüştür. Denetimde rotasyon ile denetçi bağımsızlığı arttırılarak denetim kalitesinin sağlanması amaçlanmıştır. Ancak rotasyon uygulamasının denetçi bağımsızlı̆̆ ve denetim kalitesini sağlaması hususunda çeşitli iddiaların varlığı dünyada rotasyon uygulamasını tartışmalı bir hale getirmiştir.

$\mathrm{Bu}$ araştırmada, dünyada yaşanan bu rotasyon karmaşasıyla ilgili, rotasyonun denetçi bağımsızlığ 1 ve denetim kalitesine etkisi ve rotasyon ile denetim kalitesi arasındaki ilişkide denetçi bağımsızlığının aracı rolü araştırılmıştır. 
Araştırmaya katılan denetçilerin algılarından elde edilen sonuçlara göre;

1. Denetimde rotasyon denetçi bağımsızlığını arttırmaktadır.

2. Denetimde rotasyon denetim kalitesini arttırmaktadır.

3. Denetçi bağımsızlı̆̆ı denetim kalitesini arttırmaktadır.

4. Denetimde rotasyon ile denetim kalitesi arasındaki ilişkide denetçi bağımsızlığının kısmi aracılık etkisi vardır.

5. Denetimde rotasyon denetçi bağımsızlığını arttırarak denetim kalitesini dolaylı olarak arttırmaktadır.

6. Rotasyonun denetim kalitesine dolayl1 etkisinin yan1 sira rotasyon denetim kalitesini doğrudan da etkilemektedir yani rotasyon denetçi bağımsızlı̆̆ aracıllğı olmadan da denetim kalitesini arttırmaktadır.

7. Denetimde rotasyon uygulaması ile denetçi denetim hizmetlerinde daha bağımsız, tarafsız ve objektif olacaktır.

8. Denetimde rotasyon sistemi ile denetçi-müşteri arasında uzun süreli iş ilişkisi nedeniyle oluşabilecek arkadaşlık ve güven ilişkileri önlenecek ve böylece denetçi hizmetlerinde daha bağımsız olacaktır.

9. $\quad$ Denetimde rotasyon sistemi ile denetçi müşteri hesaplarına daha şüpheci bir yaklaşım sergileyerek finansal tablolardaki önemli yanlışlıkları tespit edebilecek ve tespit edilen yanlışlıkları raporunda bildirecektir. Bu sayede denetim kalitesi artacaktır.

10. Denetimde rotasyon ile denetçi müşterisinin kendi lehine raporlama baskısına direnerek denetim raporunda uygun görüş vermesi sağlanacak ve bu sayede denetim kalitesi artacaktır.

11. Denetimde rotasyon ile denetime getirilecek yeni bir bakış açısı denetçinin denetim sürecindeki performansını arttıracak ve böylece denetçi çalışmalarında daha dikkatli ve titiz bir şekilde davranacaktır.

12. Uzun süreli iş ilişkisi denetçinin sürekli tekrarlanan rutin çalışmaları nedeniyle bazı hususlara alş̧arak değişen koşulları dikkate almadan önemli yanlışlıkları tespit edememesi veya göz ardı edebilmesine neden olabilecektir. Bu da önemli yanlışlıkların raporlanamaması veya düzeltilememesi nedeniyle nitelikli bir raporlamayı olumsuz etkileyecek ve denetim kalitesinin düşmesine neden olacaktır.

13. Denetimde rotasyon uygulaması ile denetime getirilecek yeni bir bakış açısı finansal tablolarda önceden tespit edilemeyen veya göz ardı edilen yanlışlıkların tespit edilmesini sağlayacak ve denetim hatası riskinin azaltacaktır. Böylece denetim kalitesi artacaktır.

Denetimde rotasyon uygulamasının denetçi bağımsızlığı ve denetim kalitesini arttırmada önemli bir etken olduğu görülmektedir. Ancak rotasyon uygulamasından beklenen faydaların sağlanabilmesi rotasyonun aşılmadığı durumlarda mümkün olabilecektir. Büyük denetim firmalarının kendi bünyelerinde kurdukları veya danışıklı ya da yandaş firmalar arasında müşteri değişimlerinin önüne geçilmesi gerekmektedir. Ayrıca denetçilerin tam bağımsızlığı öncelikle ekonomik bağımsızlığının sağlanması ile yani denetçi-müşteri arasındaki ücret ilişkisinin kaldırılması ile mümkün olabilecektir. Bu doğrultuda KGK bünyesinde oluşturulacak olan bir havuz sistemi ile denetlenecek işletmelerin denetim firmalarına adil bir dağıtımı sağlanarak rotasyonun aşılmasının önüne geçilebilecektir. Böylece küçük denetim firmalarının piyasaya girmeleri kolaylaşacak ve denetçilerin müşterilerine olan ekonomik bağl1lığı ortadan kalkacaktır. 
Araştırmadan elde edilen sonuçlar rotasyonun sadece sorumlu denetçi düzeyinde değil aynı zamanda denetim firması düzeyinde de uygulanması gerektiğini göstermektedir. Aksi takdirde aynı denetim firması içerisinde yapılan denetçi rotasyonu uygulaması, denetçinin denetim firmasının çıkarları doğrultunda hareket edebileceği ihtimalini değiştirmeyecektir.

$\mathrm{Bu}$ çalışmada, verilerin anket aracılığı ile elde edilmesinden dolayı anket sorularına hatalı cevapların verilebileceği ihtimali araştırmanın muhtemel kısıtlarını oluşturmaktadır. Gelecek çalışmalarda denetim ücreti ve denetim maliyeti değişkenleri de dâhil edilerek araştırmalar yapılması tavsiye edilebilir.

\section{KAYNAKLAR}

Arel, Barbara - Brody, Richard G. - Pany, Kurt (2005), “Audit Firm Rotation and Audit Quality" The CPA Journal, 75(1), pp. 36-39.

Aslanoğlu, Suphi - Baskan, Tuba Derya (2016), "Denetçilerin Bağımsızlığının Denetim Kalitesine Etkisi”, Muhasebe ve Denetime Bakış, 48, ss. 59-84.

Bağımsız Denetim Yönetmeliği. (26.12.2012 Tarih ve 28509 Sayıll, Resmi Gazetede yayınlanan)

Barbadillo, Emiliano Ruiz - Aguilar, Nieves Gomez - Carrera, Nieves (2009), "Does Mandatory Audit Firm Rotation Enhance Auditor Independence? Evidence from Spain”, Auditing A Journal of Practice \& Theory, 28(1), pp. 2-26.

Baron, Reuben M. - Kenny, David A. (1986), "The moderator-mediator variable distinction in social psychological research: Conceptual, strategic, and statistical considerations", Journal of Personality \& Social Psychology, 51(6), pp. 1173-1182.

Barton, Marquita Toinette (2002), Analysis of the Mandatory Auditor Rotation Debate, University of Tennessee Honors Thesis Projects, Tennessee-Knoxville-ABD.

Büyüköztürk, Şener (2007), Sosyal Bilimler İçin Veri Analizi El Kitabı, Pegem Akademi, Ankara.

Can, Abdullah (2013), SPSS ile Nicel Veri Analizi, Pegem Akademi, Ankara.

Ceylan, Ahmet (2007) "Kalite Güvence Standard1, Türkiye'deki Durum ve Meslek Mensubunun Sorumlulukları", 2. Türkiye Muhasebe Forumu, Ankara 30-31 Mart, 2007.

Daugherty, Brian E. - Dickins, Denise - Hatfield, Richard C. - Higgs Julia L. (2012), “An Examination Of Partner Perceptions Of Partnern Rotation: Direct And İndirect Consequences To Audit Quality", Auditing: A Journal of Practice \& Theory, 31(1), pp. 106-111.

DeAngelo, Linda Elizabeth (1981), “Auditor Size and Audit Quality”, Journal of Accounting and Economics, 3(3), pp. 183-199. 
Dinç, Yusuf - Cengiz, Selim (2014), "Muhasebe Denetiminde Hata ve Hilelerin Denetçi Etiği Açısından İncelenmesi: Enron Skandalı Örneği”, Çankırı Karatekin Üniversitesi Sosyal Bilimler Enstitüsü Dergisi, 5(1), ss. 221-236.

Doğan, Aziz (2016), "Bağımsız Denetimde Zorunlu Rotasyon", Muhasebe ve Denetim Dünyası Dergisi, (1), ss. 2-7.

Dopuch, Nicholas - King, Ronald R. - Schwartz, Rachel (2001), “An Experimental Investigation of Retention and Rotation Requirements", Journal of Accounting Research, 39(1), pp. 95-116.

Field, Andy (2013), Discovering Statistics Using IBM SPSS Statistics, 4Th Edition, Sage Publications Ltd., London.

Firth, Michael - Rui, Oliver M. - Wu, Xi (2012), “How Do Various Forms of Auditor Rotation Affect Audit Quality? Evidence from China", The International Journal of Accounting, 47(1), pp. 109-115.

Gürbüz, Sait ve Şahin, Faruk (2016), Sosyal Bilimlerde Araştırma Yöntemleri, 3. Bask1, Seçkin Yayıncılık, Ankara.

Güredin, Ersin (2008), Denetim ve Güvence Hizmetleri, 12. Bask1, Türkmen Kitapevi, İstanbul.

Haftac1, Vasfi (2016), Muhasebe Denetimi, 4. Bask1, Umuttepe Yayınları, Kocaeli.

Hayes, Andrew F. (2013), PROCESS Procedure for SPSS Release 2.13. URL: www.guilford.com/p/hayes3 (13.01.2019).

Independence Standart Board-ISB, (2000), "Statement of Independence Concepts A Conceptual Framework for Auditor Independence", Exposure Draft: ED 00-2. https://www.icjce.es/images/pdfs/TECNICA/C03\%20-\%20AICPA/C309\%20-\%20 Otras\%20entidades/ISB\%20-\%20ED002\%20\%20Conceptual\%20framework \%20auditor\%20independence\%20-\%20Nov\%202000.PDF (18.04.2018).

Jian, Ko Sie - Shi, Koh Hui - Ying, Lee Rui - Kaili, Lim - Chiang, Qek Ven (2012), “An Investingation Into Big 4 Auditing Companies in Malaysia: Factors that Affect Auditor Independence, University Tunku Abdul Rahman, A Research Project Submitted in Partial Fulfilment of The Requirement for the Degree Of, Malaysia.

Khasharmeh, Hussein \& Said, Kousay (2014a), "Auditor's Perceptions on Impact of Mondatory Audit Firm Rotation on Auditor Independence - Evidence From Bahrain", Journal of Accounting and Taxation, 6(1), pp. 1-18.

Khasharmeh, Hussein \& Said, Kousay (2014b), "Effects of Mondatory Audit Firm Rotation Upon Quality of Audit: The Peception of Audit Firms - Evidence From Bahrain", Journal of Modern Accounting and Auditing, 10(4), pp. 436-438. 
Knapp, Michael C. (1985), "Audit Conflict: An Empirical Study of the Perceived Ability of Auditors to Resist Management Pressure", The Accounting Rewiew, 60(2), pp. 202 211.

Kurtuluş, Kemal (2006), Pazarlama Araştırmaları, 8. Baskı, Literatür Yayıncılık, İstanbul.

Magolis, David E. - Staley, A. Blair - Usry, Mark L. - Leinbach, Wilmer - Shapeero, Mike Luck, Heather (2011), "Toward An Understanding Of Audit Firm Rotation As Public Polıcy: A Historical And Theoretical Perspectıve", Journal of the Northeastern Association of Business, Economics and Technology, 17(1), pp. 13-18.

Olowookere, Johnson Kolawole - Adebiyi, Waidi Kareem (2013), "Mondatory Audit Firm Rotation and Audit Quality in Nigeryan Deposit Money Banks", International Journal of Bisiness and Management Invention, 2(9), pp. 63-69.

Preacher, Kristopher J. - Andrew F. (2008), “Asymptotic and Resampling Strategies for Assessing and Comparing Indirect Effects in Multiple Mediator Models", Behavior Research Methods, 40(3) pp. 879-891.

Preacher, Kristopher J. - Hayes, Andrew F. (2004), "SPSS and SAS Procedures for Estimating Indirect Effect in Simple Mediation Models", Behavior Research Methods, Instruments, \& Computers, 36(4), pp. 717-731.

Salleh, Kalsom - Jasmani, Hazlina (2014), "Audit Rotation and Audit Report: Empirical Evidence From Malaysian PLCs over the Period of Ten Years", Procedia - Social and Behavioral Sciences, 145, pp. 40-49.

Selimoğlu, Seval Kardeş - Özbirecikli, Mehmet - Uzay, Şaban - Uyar, Süleyman (2015), Bağımsız Denetim, TÜRMOB Yayınları, Ankara.

Selimoğlu, Seval Kardeş - Özbirecikli, Mehmet - Uzay, Şaban - Uyar, Süleyman (2017), Bağımsız Denetim, Nobel Yayınları, Ankara.

Simmons, Tirisha N. - Costigan, Michael L. - Lovata, Linda M. (2009), "Mandatory Audit Firm Rotation: Evidence From Illinois State Universities", Academy of Accounting and Financial Studies Journal, 13(3), pp. 123-132.

Siregar, Sylvia Veronica - Amarullah, Fitriany - Wibowo, Arie - Anggraita, Wiska (2012), "Audit Tenure, Auditor Rotation, and Audit Quality: The Case of Indonesia", Asian Journal of Business and Accounting, 5(1), pp. 69-71.

Şavlı, Tuba (2016), “Türkiye'de Bağımsız Denetimde Rotasyon: Düzenlemeler, Uygulamalar ve Öneriler”, Mali Ç özüm Dergisi, 26(134), ss. 37-53.

Tavşancıl, Ezel (2010), Tutumların Ölçülmesi ve SPSS ile Veri Analizi, Nobel Yayın Dağıtım Tic. Ltd. Şti., Ankara. 
Tuan, Koray (2015), “Bağımsız Denetimde Rotasyon Uygulaması: Sistemin Artıları Eksileri Üzerine Tartışmalar’, Akademik Sosyal Araştırmalar Dergisi, 16, ss. 297 309.

Vitalis, Kukeng - Patrick, Zayol - Mdoom, Iortule (2017) “'Effect of Auditor Independence on Audit Quality: A Review of Literature", International Journal of Business and Management Invention, 6(3), pp. 56-59.

Yazıcıoğlu, Yahşi - Erdoğan, Samiye (2007), SPSS Uygulamalı Bilimsel Araştırma Yöntemleri, Detay Yayıncılık, Ankara. 